\title{
Efficacy of Selected Herbicide Programs in 2,4-D Tolerant Cotton (Gossypium hirsutum L.)
}

\author{
Colton H. Sanders' ${ }^{1}$, Dwayne D. Joseph ${ }^{2}$, Michael W. Marshall ${ }^{1}$ \\ ${ }^{1}$ Edisto Research and Education Center, Clemson University, Blackville, SC, USA \\ ${ }^{2}$ Department of Plant and Environmental Sciences, Clemson University, Clemson, SC, USA \\ Email: coltons@clemson.edu,dwaynej@g.clemson.edu,marsha3@clemson.edu
}

How to cite this paper: Sanders, C.H., Joseph, D.D. and Marshall, M.W. (2017) Efficacy of Selected Herbicide Programs in 2,4-D Tolerant Cotton (Gossypium hirsutum L.). Agricultural Sciences, 8, 1157-1167. https://doi.org/10.4236/as.2017.810084

Received: September 19, 2017

Accepted: October 24, 2017

Published: October 27, 2017

Copyright ( 92017 by authors and Scientific Research Publishing Inc. This work is licensed under the Creative Commons Attribution International License (CC BY 4.0).

http://creativecommons.org/licenses/by/4.0/

(c) (i) Open Access

\begin{abstract}
The use of transgenic crops has grown significantly over the past couple of decades. Many agronomic crops produced today are tolerant to glyphosate. Glyphosate-tolerant crops were commercially introduced in 1996, and, about nine years later, glyphosate-resistant Palmer amaranth was confirmed in Georgia. Glyphosate-resistant weeds arose from reliance on postemergence only glyphosate programs to control weeds in crops. New transgenic traits for glufosinate and 2,4-D choline have been developed, and evaluations of stacked traits and concurrent use of multiple herbicides have provided additional tools in the management of glyphosate-resistant weeds. Field experiments were conducted in 2012 and 2013 at the Edisto Research and Education Center near Blackville, SC, USA to determine the efficacy of 2,4-D-based herbicide programs in transgenic cotton tolerant to 2,4-D choline, glyphosate, and glufosinate. The treatments provided good to excellent Palmer amaranth and pitted morningglory control in 2012 and 2013. Seed cotton yields across treatments ranged from 0 to $2057 \mathrm{~kg} \mathrm{ha}^{-1}$. This new trait technology package in cotton permits in-season postemergence use of 2,4-D choline, a herbicide mode of action not previously used postemergence in cotton, which can control resistant weeds, including Palmer amaranth if applied at the proper growth stage.
\end{abstract}

\section{Keywords}

Glyphosate, 2,4-D Tolerant Cotton, Resistant Weeds, Glufosinate, 2,4-D Choline, Weed Control

\section{Introduction}

In 1996, cotton and other crops tolerant to the herbicide glyphosate were commercialized and released to the market [1]. The adoption and use of genetically 
modified crops have increased dramatically over the past 20 years in corn (Zea mays L.), soybean (Glycine max L.), and cotton. For example, in 2016, 93\% of the USA cotton hectares were planted with seed containing tolerance to the herbicide glyphosate [2] [3]. Initially, glyphosate was very effective in managing a broad spectrum of weeds; however, reliance on a single site of action over a broad geographic area dramatically increased the selection pressure which led to the selection and spread of several glyphosate-resistant weed biotypes in cotton [4] [5].

Palmer amaranth (Amaranthus palmeri S. Wats) is a warm season annual dioecious broadleaf plant [6]. Currently, the most common and troublesome weed in cotton in the Southern US is Palmer amaranth due to its rapid growth rate, prolific seed production, and high competitiveness [5] [6] [7]. Cotton lint yield can be drastically reduced by the presence of Palmer amaranth [8] [9] [10]. Previous research has shown that lint yields can be reduced from as few as 1 to 2 Palmer amaranth plants per row meter [8]. Palmer amaranth competition not only causes yield losses, but it can also increase the cost of production and its large stature can impede the harvesting efficiency of cotton [9].

Palmer amaranth has previously developed resistance to several herbicide groups, including to the dinitroanilines, ALS-inhibitors, and glyphosate groups [5]. Dinitroaniline resistant Palmer amaranth biotypes were confirmed in 1992 in South Carolina [11]. In a peanut field in Georgia, Palmer amaranth biotypes were confirmed to be resistant to ALS-inhibitor herbicides in 2000 [12]. The over reliance on glyphosate postemergence only programs has led to rapid selection and spread of resistant Palmer amaranth biotypes throughout the Southern US and is causing huge economic losses in these crops. Therefore, glyphosate-resistant biotypes of Palmer amaranth have spread rapidly since their confirmation in 2005 [4] [13].

Synthetic auxin herbicides, such as 2,4-D, selectively control broadleaf weeds, including Palmer amaranth [14]. Auxinic herbicides cause uncontrolled increases in cell wall growth and cell division which leads to abnormal development in the meristematic tissue in susceptible plants [15]. Dow AgroSciences has developed a new salt formulation of 2,4-D called 2,4-D choline that is significantly less volatile than previous salt formulations. Enlist $\mathrm{Duo}^{\mathrm{mm}}$ is a prepackaged mixture of $0.19 \mathrm{~kg}$ ae $\mathrm{L}^{-1}$ of 2,4-D choline and $0.2 \mathrm{~kg}$ ae $\mathrm{L}^{-1}$ of glyphosate [16].

Dow AgroSciences has recently developed and released transgenic cotton varieties with genetic tolerance to the postemergence applications of 2,4-D, glyphosate, and glufosinate. The availability of 2,4-D choline and glufosinate for in-crop postemergence applications will aid in effective management of glyphosate-resistant Palmer amaranth and other broadleaf weeds in these transgenic varieties. Previous research has shown that timely applications of 2,4-D can effectively control a range of broadleaf weed species including common lambsquarters (Chenopodium album L.), common waterhemp (Amaranthus rudis Sauer.), giant ragweed (Ambrosia trifida L.), Palmer amaranth, annual mor- 
ningglory (Ipomoea spp.) and velvetleaf (Abutilon theophrasti Medik) [17] [18] [19]. This will provide cotton growers with additional modes of action for troublesome broadleaf weeds.

The Enlist Duo herbicide, in combination with at-plant and postemergence soil residual herbicides, will be beneficial in managing existing populations of herbicide-resistant broadleaf weeds in cotton. Previously, herbicide programs evaluated that began with an at-plant residual herbicide provided the most consistent season-long weed control and resulted in the lowest density of reproductive Palmer amaranth plants prior to harvest [19]. The 2,4-D choline herbicide will aid control of Palmer amaranth biotypes resistant to multiple modes-of-action and help delay or prevent the development of additional resistant biotypes. Because this technology is new, very little research has been conducted on the efficacy of in-season postemergence 2,4-D choline based herbicide programs on economically important weeds in 2,4-D tolerant cotton. Therefore, research was initiated to evaluate selected 2,4-D choline based herbicide combinations on weed control and their effects on 2,4-D tolerant cotton growth and yield.

\section{Materials and Methods}

Field experiments were conducted on a Varina sandy loam ( $\mathrm{pH}$ of 6.1 and organic matter of 1.3\%), (fine, kaolinitic, thermic Plinthic Paleudults) at the Clemson University Edisto Research and Education Center $\left(33.36^{\circ} \mathrm{N},-81.32^{\circ} \mathrm{W}\right)$ located near Blackville, SC, USA in 2012 and 2013 to determine the efficacy of 2,4-D based herbicide programs for weed control in 2,4-D tolerant cotton. The cotton variety "pDAB4468" (Dow AgroSciences; Indianapolis, IN, USA) was seeded using a four-row Almaco cone plot planter (Almaco, Nevada, IA, USA) $1.25 \mathrm{~cm}$ deep in rows spaced $96 \mathrm{~cm}$ apart on 15 June 2012 and 21 June 2013 in a conventionally-tilled soil at 10 seed $\mathrm{m}^{-1}$. Treated plot dimensions were two rows wide and $9.4 \mathrm{~m}$ long. In both study years, soybean was the previous year's crop grown at each location.

The experimental design was a randomized complete block of four row plots with four replications. All field maintenance processes, such as fertilizing, defoliation, and insect control, were followed according to recommended production practices for cotton in South Carolina [20]. The middle two rows represented the treated area and outside rows were used as an untreated control. In the two studies conducted in 2012 and 2013, the herbicide treatments are presented in Table 1 . The application rates selected for the 2,4-D choline and glyphosate (Enlist Duo) treatments were based on the use rates recommended on the herbicide label [16]. The remaining treatments in the studies were selected based on the standard Extension herbicide programs used in cotton production in South Carolina. Herbicides were applied in water using a $\mathrm{CO}_{2}$ pressurized backpack sprayer which delivered $140 \mathrm{~L} \mathrm{ha}^{-1}$ at $235 \mathrm{kPa}$ via a four-nozzle boom fitted with Turbo TeeJet ${ }^{\circledR} 11002$ Induction Flat Spray nozzles (Teejet, Spraying Systems Co., 
Table 1. Herbicide treatments, application timing, and rates for 2,4-D based herbicide program evaluations.

\begin{tabular}{|c|c|c|c|c|}
\hline No. & Treatment $^{a}$ & Timing $^{\mathrm{b}}$ & Rate $^{c}$ & Product Name \\
\hline \multicolumn{5}{|c|}{$\mathrm{kg}$ ai ha- ${ }^{-1}$ or kg ae ha ${ }^{-1}$} \\
\hline 1 & Untreated Check & --- & --- & --- \\
\hline \multirow{3}{*}{2} & fomesafen & PRE & 0.28 & Reflex \\
\hline & 2,4-choline + glyphosate & POST1 & $0.55+0.55$ & Enlist Duo \\
\hline & 2,4-choline + glyphosate & POST2 & $0.55+0.55$ & Enlist Duo \\
\hline \multirow{3}{*}{3} & fomesafen & PRE & 0.28 & Reflex \\
\hline & 2,4 choline + glyphosate & POST1 & $0.82+0.82$ & Enlist Duo \\
\hline & 2,4 choline + glyphosate & POST2 & $0.82+0.82$ & Enlist Duo \\
\hline \multirow{3}{*}{4} & fomesafen & PRE & 0.28 & Reflex \\
\hline & 2,4 choline + glyphosate + glufosinate & POST1 & $0.82+0.82+0.59$ & Enlist Duo + Liberty \\
\hline & 2,4 choline + glyphosate & POST2 & $0.82+0.82$ & Enlist Duo \\
\hline \multirow{3}{*}{5} & fomesafen & PRE & 0.28 & Reflex \\
\hline & 2,4 choline + glyphosate + glufosinate & POST1 & $0.82+0.82+0.59$ & Enlist Duo + Liberty \\
\hline & glufosinate & POST2 & 0.59 & Liberty \\
\hline \multirow{3}{*}{6} & fomesafen & PRE & 0.28 & Reflex \\
\hline & 2,4 choline + glyphosate + acetochlor & POST1 & $0.82+0.82+1.26$ & Enlist Duo + Warrant \\
\hline & 2,4 choline + glyphosate & POST2 & $0.82+0.82$ & Enlist Duo \\
\hline \multirow{3}{*}{7} & fomesafen & PRE & 0.28 & Reflex \\
\hline & glyphosate & POST1 & 0.84 & Roundup PowerMAX \\
\hline & glyphosate & POST2 & 0.84 & Roundup PowerMAX \\
\hline \multirow{3}{*}{8} & fomesafen & PRE & 0.28 & Reflex \\
\hline & glufosinate & POST1 & 0.59 & Liberty \\
\hline & glufosinate & POST2 & 0.59 & Liberty \\
\hline \multirow{3}{*}{9} & fomesafen & PRE & 0.28 & Reflex \\
\hline & glufosinate + acetochlor & POST1 & $0.59+1.26$ & Liberty + Warrant \\
\hline & glyphosate & POST2 & 0.84 & Roundup PowerMAX \\
\hline
\end{tabular}

${ }^{\mathrm{a}}$ All POST treatments included ammonium sulfate at $2.5 \% \mathrm{v} / \mathrm{v}$. ${ }^{\mathrm{b}}$ Treatment timing: PRE, at planting; POST1, 5 - $10 \mathrm{~cm}$ weeds; POST2, 21 days after POST1. 'Active ingredients (ai) rate used for fomesafen, glufosinate, and acetochlor. Acid equivalent (ae) rate used for 2,4-D choline and glyphosate.

Wheaton, IL, USA) at a ground speed of $5 \mathrm{~km} \mathrm{~h}^{-1}$.

All plots, except the untreated control, was treated with a preemergence (PRE) application of fomesafen at $0.28 \mathrm{~kg}^{\mathrm{ai} \mathrm{ha}} \mathrm{ha}^{-1}$ at planting and followed up with two postemergence herbicide combinations (POST1 and POST2). The POST1 treatments were applied 26 days after planting (DAP) when Palmer amaranth and pitted morningglory (Ipomoea lacunosa L.) sizes ranged from 5 to $10 \mathrm{~cm}$ in height. The POST2 combinations were sprayed 47 DAP when Palmer amaranth 
and pitted morningglory sizes ranged from 10 to $15 \mathrm{~cm}$ in height. Data collected included visual ratings of percent control of weeds, estimates of weed populations in plots, crop response or injury, and seed cotton yield. Visual ratings for crop injury and percent weed control were taken on a scale of $0 \%-100 \%$, with $0 \%$ indicating no effect on cotton or weed populations, respectively, and $100 \%$ indicating crop death or complete weed control, respectively. Visual ratings of control were collected 3 weeks after POST 1 ( 3 WAP1) and 2 weeks after POST 2 (2 WAP2). Weed species population densities were estimated at the 2 WAP2 application timing by randomly tossing a $0.5 \mathrm{~m}^{2}$ quadrat down the middle of the 2 treated rows and each weed species present was identified and counted. The middle two treated rows were harvested using a two-row spindle type picker and weighed in kg per plot on 11 November 2012 and 11 December 2013. Harvest weights for each plot were then converted into kg per hectare.

Ratings of weed control, estimates of weed density, and cotton yield data were subjected to ANOVA using the PROC GLM procedure in SAS (SAS 9.4, SAS ${ }^{\circledR}$ Institute Inc. Cary, NC, USA), with herbicide treatment and years as the main effect and replication as the random effect. Percent weed control and population densities were combined over trial years if no significant treatment by year was observed. Means of significant main effects were separated using Fisher's Protected LSD at $\mathrm{P} \leq 0.05$.

\section{Results and Discussion}

This research showed differences among treatments and treatment by year across all rating periods. Weed control and population density data were presented separately if there was a treatment by year interaction, and averaged over both years when there was no significant interaction.

The monthly precipitation accumulation and average temperature data at the experimental sites during 2012 and 2013 are presented in Table 2. In 2012, a total of $740 \mathrm{~mm}$ rainfall was received during the growing season and $693 \mathrm{~mm}$ rainfall was received in 2013 at the study sites.

Soil active herbicides, such as fomesafen, require a minimum amount of precipitation after application for proper activation in the soil. In June 2012, rainfall received when the studies were initiated in the field was $81 \mathrm{~mm}$. However, rainfall accumulation in June 2013 was much higher $(178 \mathrm{~mm})$. Despite, the lower amount of precipitation received during planting in 2012, fomesafen was properly activated based on the level of weed control observed after planting in both years. During July, August, and September, precipitation accumulation was 427 and $403 \mathrm{~mm}$ in 2012 and 2013, respectively (Table 2). The highest average air temperature was observed during the month of July $\left(29^{\circ} \mathrm{C}\right.$ in 2012 and $27^{\circ} \mathrm{C}$ in 2013). However, in 2013, May and August were also comparable to July average air temperatures indicating that effects of heat stress on the plants were experienced over a much longer period than in 2012. Average air temperatures decreased rapidly after September in 2012 and 2013. 
Table 2. Monthly rainfall totals and average temperatures observed at the study sites during the growing season at Edisto Research and Education Center located near Blackville, SC, USA, for the months of May through November in 2012 and 2013.

\begin{tabular}{ccccc}
\hline \multirow{2}{*}{ Month } & \multicolumn{2}{c}{ Monthly Precipitation } & \multicolumn{2}{c}{ Monthly Average Air Temperature } \\
\cline { 2 - 5 } & 2012 & 2013 & 2012 & 2013 \\
\cline { 2 - 5 } May & 173 & 64 & 24 & 23 \\
June & 81 & 178 & 26 & 27 \\
July & 97 & 230 & 29 & 27 \\
August & 310 & 134 & 26 & 27 \\
September & 20 & 39 & 24 & 25 \\
October & 14 & 5 & 19 & 20 \\
November & 45 & 43 & 12 & 13 \\
Total & 740 & 693 & - & - \\
\hline
\end{tabular}

\subsection{Palmer Amaranth Control}

Estimates for control and density of Palmer amaranth resulted in some differences between treatments (Table 3). Palmer amaranth visual control and population density did not have a significant treatment by year interaction; as a result, data was combined for 2012 and 2013. The PRE application of fomesafen provided early season control of Palmer amaranth across all treatments ranging 91\% - $100 \%$ at 3 weeks after planting, excluding the untreated check.

At 3 WAP1, the glyphosate POST1 followed by glyphosate POST2 (TRT 7) only provided $95 \%$ and $94 \%$ control at the 3 WAP1 and 2 WAP2 evaluations periods, respectively, indicating that the natural Palmer amaranth populations at the study sites were predominately sensitive to glyphosate. The addition of 2,4-D choline improved Palmer amaranth control in all treatments (TRT 2 - 4 and 5 6) (100\% at 2 WAP2). Similarly, Joseph [21] and Miller [19] observed 93\% $100 \%$ control of Palmer amaranth with 2,4-D choline plus glyphosate in 2,4-D tolerant soybean. However, Merchant [18] observed lower values of Palmer amaranth control with 2,4-D alone. Glufosinate POST1 followed by glufosinate POST2 (TRT 8) and glufosinate plus acetochlor POST1 followed by glyphosate POST2 (TRT 9) provided excellent control of Palmer amaranth at 2 WAP2. Estimates of the Palmer amaranth population trended with the visual control ratings in all treatments with the untreated control significantly higher at 5 plants $\mathrm{m}^{-2}$ than the herbicide treatments (TRT 2 - 9) (Table 3).

\subsection{Pitted Morningglory Control}

There was greater variability in the pitted morningglory population counts and visual percent control between treatments compared to Palmer amaranth (Table 4). A treatment by year interaction was observed with the 3 WAP1 and 2 WAP2 
Table 3. Palmer amaranth (AMAPA) percent visual control and population density counts as affected by herbicide treatments in 2012 \& 2013.

\begin{tabular}{|c|c|c|c|}
\hline \multirow{3}{*}{ TRT No. ${ }^{a}$} & \multicolumn{2}{|c|}{ AMAPA control ${ }^{\mathrm{b}}$} & \multirow{3}{*}{$\begin{array}{c}\text { AMAPA density } \\
2 \mathrm{WAP}^{\mathrm{c}} \\
\text { plants } \mathrm{m}^{-2} \\
\end{array}$} \\
\hline & $3 \mathrm{WAP}^{\mathrm{c}}$ & $2 \mathrm{WAP}^{\mathrm{c}}$ & \\
\hline & \multicolumn{2}{|c|}{$\%$} & \\
\hline 1 & - & - & $5.0 \mathrm{a}$ \\
\hline 2 & $100 \mathrm{a}$ & $100 \mathrm{a}$ & $0 \mathrm{c}$ \\
\hline 3 & $100 \mathrm{a}$ & $100 \mathrm{a}$ & $0 \mathrm{c}$ \\
\hline 4 & $98 \mathrm{ab}$ & $100 \mathrm{a}$ & $0 \mathrm{c}$ \\
\hline 5 & $99 \mathrm{ab}$ & $100 \mathrm{a}$ & $0 \mathrm{c}$ \\
\hline 6 & $100 \mathrm{a}$ & $100 \mathrm{a}$ & $0 \mathrm{c}$ \\
\hline 7 & $95 \mathrm{~b}$ & $94 \mathrm{~b}$ & $1 \mathrm{~b}$ \\
\hline 8 & $96 \mathrm{ab}$ & $100 \mathrm{a}$ & $0 \mathrm{c}$ \\
\hline 9 & $100 \mathrm{a}$ & $100 \mathrm{a}$ & $0 \mathrm{c}$ \\
\hline
\end{tabular}

${ }^{\mathrm{a} R e f e r ~ t o ~ T a b l e ~} 1$ for treatment (TRT) names and rates; ${ }^{\mathrm{b}}$ Means followed by the same letter do not differ significantly according to Fishers Protected LSD at 5\%; ${ }^{~}$ Palmer amaranth percent control and population density rating periods: 3 weeks after POST1 (3 WAP1) and 2 weeks after POST2 application (2 WAP2).

Table 4. Pitted morningglory (IPOLA) percent visual control and population density counts as affected by herbicide treatments for pitted morningglory in 2012 \& 2013.

\begin{tabular}{|c|c|c|c|c|c|c|}
\hline \multirow{4}{*}{ TRT No. ${ }^{a}$} & \multicolumn{4}{|c|}{ IPOLA control $^{\mathrm{b}}$} & \multirow{2}{*}{\multicolumn{2}{|c|}{$\frac{\text { IPOLA density }^{\mathrm{b}}}{2 \mathrm{WAP}^{\mathrm{c}}}$}} \\
\hline & \multicolumn{2}{|c|}{$3 \mathrm{WAP}^{\mathrm{c}}$} & \multicolumn{2}{|c|}{$2 \mathrm{WAP}^{\mathrm{c}}$} & & \\
\hline & \multicolumn{4}{|c|}{$\%$} & \multicolumn{2}{|c|}{ plants $\mathrm{m}^{-2}$} \\
\hline & 2012 & 2013 & 2012 & 2013 & 2012 & 2013 \\
\hline 1 & - & - & - & - & $11.0 \mathrm{a}$ & $11.0 \mathrm{a}$ \\
\hline 2 & $95 \mathrm{abc}$ & $88 \mathrm{abc}$ & $96 \mathrm{a}$ & $90 \mathrm{ab}$ & $1 \mathrm{c}$ & $0 \mathrm{~b}$ \\
\hline 3 & $94 \mathrm{a}-\mathrm{d}$ & $83 c$ & $98 \mathrm{a}$ & $80 \mathrm{c}$ & $1 \mathrm{c}$ & $0 \mathrm{~b}$ \\
\hline 4 & $96 \mathrm{ab}$ & $85 \mathrm{bc}$ & $99 \mathrm{a}$ & $87 b c$ & $1 \mathrm{c}$ & $0 \mathrm{~b}$ \\
\hline 5 & $97 \mathrm{a}$ & $83 \mathrm{c}$ & $96 \mathrm{a}$ & $80 \mathrm{c}$ & $0 \mathrm{~d}$ & $0 \mathrm{~b}$ \\
\hline 6 & 94 a-d & $90 \mathrm{a}$ & $95 \mathrm{ab}$ & $88 \mathrm{ab}$ & $7 \mathrm{ab}$ & $0 \mathrm{~b}$ \\
\hline 7 & $89 \mathrm{bcd}$ & $90 \mathrm{a}$ & $89 c$ & $90 \mathrm{ab}$ & $6 \mathrm{ab}$ & $0 \mathrm{~b}$ \\
\hline 8 & $85 \mathrm{~d}$ & $88 \mathrm{abc}$ & $96 \mathrm{a}$ & $88 \mathrm{ab}$ & $2 b c$ & $0 \mathrm{~b}$ \\
\hline 9 & $87 \mathrm{~cd}$ & $88 \mathrm{abc}$ & $95 \mathrm{ab}$ & $92 \mathrm{a}$ & $3 \mathrm{bc}$ & $1 \mathrm{~b}$ \\
\hline
\end{tabular}

${ }^{a}$ Refer to Table 1 for treatment (TRT) names and rates; ${ }^{b}$ Means followed by the same letter do not differ significantly according to Fishers Protected LSD at 5\%; 'Pitted morningglory percent control and population density rating periods: 3 weeks after POST1 (3 WAP1) and 2 weeks after POST2 application (2 WAP2).

pitted morningglory rating dates; therefore, data are presented by year. Treatments were sprayed with fomesafen PRE, and significant differences in control of pitted morningglory ( $83 \%$ to $100 \%$ ) were observed between treatments at 3 weeks after planting, excluding the untreated check. At 3 WAP1, treatments 
(TRT 2 - 6) that included 2,4-D choline at POST1 provided 94\% to 99\% control of pitted morningglory; however, in treatments without 2,4-D choline (TRT 7 9), control declined to $85 \%$ to $89 \%$ for 2012 (Table 4). In a similar study, Merchant [21] found that the control of pitted morningglory increased when an auxinic herbicide was mixed with glufosinate rather than sprayed alone. At 2 WAP2, control of pitted morningglory was greater than $90 \%$ in 2012 with all treatments (TRT 2 - 6) containing 2,4-D choline and glyphosate combinations (Table 4). Estimates of pitted morningglory density trended with visual ratings of percent control for 2012; however, no differences were observed between TRT 6 and 7 and the untreated control (TRT 1). In 2013, pitted morningglory densities in the untreated check (TRT 1) were significantly higher at 11 plants $\mathrm{m}^{-2}$ compared to the remaining herbicide treatments (TRT 2 - 9).

Significant differences among the treatments were observed with the pitted morningglory percent control ratings and population counts. Pitted morningglory control in 2013 was less than in 2012 with ranges being from $83 \%$ to $90 \%$ at 3 WAP1 (TRT 2 - 6). The 2,4-D choline + glyphosate + glufosinate and 2,4-D choline + glyphosate treatments (TRT 3 and 5) resulted in the lowest control of $83 \%$ at 3 WAP1 in 2013 (Table 4). Other studies have reported that auxin herbicides mixed with glufosinate provided excellent control of morningglory species [8] [22]. Culpepper [23] also observed that 2,4-DB plus glyphosate provided control of annual morningglory. Estimates of pitted morningglory density did not correspond to the visual control ratings in 2013 because control ratings took into account the climbing nature of the plant. Overall, pitted morningglory population densities across the treatments were significantly less than the untreated control (11 plants $\mathrm{m}^{-2}$ at $\left.2 \mathrm{WAP} 2\right)$.

\subsection{Cotton Yield}

In 2012, seed cotton yield ranged from 534 to $2057 \mathrm{~kg} \mathrm{ha}^{-1}$ in the untreated check (TRT 1) and 2,4-D choline + glyphosate at POST 1 and 2 (TRT 3), respectively (Table 5). Among the treatments, glufosinate followed by glufosinate was numerically the lowest yield at $1358 \mathrm{~kg} \mathrm{ha}^{-1}$. The seed cotton yield harvested from the plots in 2013 ranged from 0 to $647 \mathrm{~kg} \mathrm{ha}^{-1}$ and was far lower overall than in 2012. Rainfall and temperature were adequate through the growing season in 2013; however, the plots were collected later than normal due to plot equipment malfunctions and conflicting scheduling resulting in boll degradation and yield loss before harvest. Although yields were much lower in 2013, the 2,4-D choline + glyphosate at POST 1 and 2 treatment (TRT 3) also had the highest yield which was similar to 2012 .

\section{Summary}

Overall, this research showed that herbicide programs including 2,4-D choline + glyphosate and glufosinate were more effective on Palmer amaranth and pitted morningglory, than the treatments without 2,4-D choline. However, weed size 
Table 5. Mean seed cotton yield as affected by selected herbicide programs in 2012 \& 2013.

\begin{tabular}{ccc}
\hline & \multicolumn{2}{c}{ Seed Cotton Yield $^{\mathrm{b}}$} \\
\cline { 2 - 3 } TRT No. $^{\mathrm{a}}$ & 2012 & 2013 \\
\cline { 2 - 3 } & \multicolumn{2}{c}{$\mathrm{kg} \mathrm{ha}^{-1}$} \\
\hline 1 & $534 \mathrm{~d}$ & $0 \mathrm{~d}$ \\
3 & $1679 \mathrm{ab}$ & $7 \mathrm{bcd}$ \\
4 & $2057 \mathrm{a}$ & $647 \mathrm{a}$ \\
5 & $1660 \mathrm{ab}$ & $7 \mathrm{bcd}$ \\
6 & $1983 \mathrm{ab}$ & $49 \mathrm{abcd}$ \\
7 & $1541 \mathrm{ab}$ & $0 \mathrm{~d}$ \\
8 & $1554 \mathrm{ab}$ & $4 \mathrm{~cd}$ \\
9 & $1358 \mathrm{abc}$ & $300 \mathrm{ab}$ \\
\hline
\end{tabular}

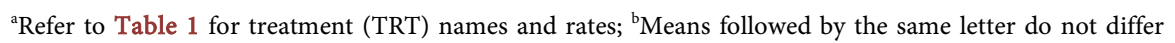
significantly according to Fishers Protected LSD at $5 \%$.

at the time of POST application will be a critical consideration for economical control. The application of fomesafen PRE reduced the early season emergence of Palmer amaranth and pitted morningglory. The overall success of 2,4-D choline containing POST herbicide programs is reliant on the use of a soil residual herbicide at planting plus the use of residual herbicides at each application timing (overlapping residuals). Without an at-plant PRE herbicide, weed size and density will quickly reach beyond the recommendations by the time that the over-the-top application of 2,4-D choline is completed reducing the efficacy of the herbicide application.

In 2012, the seed cotton yield was consistent across all treatments, especially in the treatments containing 2,4-D choline which indicates that cotton is very tolerant to the over-the-top herbicides in this study. The use of 2,4-D choline in the 2,4-D tolerant cotton will be very effective tool in managing broadleaf weeds and, most importantly, reduce the possibility of selecting new herbicide resistant biotype weeds. However, growers must utilize a comprehensive management program that includes a PRE herbicide, such as fomesafen, at planting followed by tank mixing residual herbicides, such as acetochlor and s-metolachlor, with each 2,4-D choline POST application (i.e., overlapping residuals).

\section{Acknowledgements}

Technical Contribution No. 6588 of the Clemson University Experiment Station. This material is based upon work supported by the NIFA/USDA, under project number SC-1700499. Any opinions, findings, conclusions or recommendations expressed in this publication are those of the author(s) and do not necessarily reflect the view of the USDA. 


\section{Disclaimer}

Mention of a trade name does not imply endorsement of the product by Clemson University to the exclusion of others that might be available.

\section{References}

[1] Fernandez-Cornejo, J. and McBride, W.D. (2002) The Adoption of Bioengineered Crops. U.S. Department of Agriculture Economic Research Service, AER-810, 61 p.

[2] [USDA-NASS] U.S. Department of Agriculture-National Agricultural Statistics Service (2016). Acreage. http://usda.mannlib.cornell.edu/usda/nass/Acre//2010s/2016/Acre-06-30-2016.pdf

[3] Owen, M.D. and Zelaya, I.A. (2005) Herbicide-Resistant Crops and Weed Resistance to Herbicides. Pest Management Science, 61, 301-311. https://doi.org/10.1002/ps.1015

[4] Culpepper, A.S., Grey, T.L., Vencill, W.K., Kichler, J.M., Webster, T.M., Brown, S.M., York, A.C., Davis, J.W. and Hanna, W.W. (2006) Glyphosate-Resistant Palmer Amaranth (Amaranthus palmeri) Confirmed in Georgia. Weed Science, 54, 620-626. https://doi.org/10.1614/WS-06-001R.1

[5] Heap, I.M. (2017) The International Survey of Herbicide Resistant Weeds. http://www.weedscience.com

[6] Horak, M.J. and Loughin, T.M. (2000) Growth Analysis of Four Amaranthus Species. Weed Science, 48, 347-355. http://www.jstor.org/stable/pdf/4046301 https://doi.org/10.1614/0043-1745(2000)048[0347:GAOFAS]2.0.CO;2

[7] Burke, I.C., Schroeder, M., Thomas, W.E. and Wilcut, J.W. (2007) Palmer Amaranth Interference and Seed Production in Peanut. Weed Technology, 21, 367-371. https://doi.org/10.1614/WT-06-058.1

[8] Morgan, G.D., Baumann, P.A. and Chandler, J.M. (2001) Competitive Impact of Palmer Amaranth (Amaranthus palmeri) on Cotton (Gossypium hirsutum) Development and Yield. Weed Technology, 15, 408-412. https://doi.org/10.1614/0890-037X(2001)015[0408:CIOPAA]2.0.CO;2

[9] Smith, D.T., Baker, R.V. and Steele, G.L. (2000) Palmer Amaranth (Amaranthus palmeri) Impacts on Yield, Harvesting, and Ginning in Dryland Cotton (Gossypium hirsutum). Weed Technology, 14, 122-126. https://doi.org/10.1614/0890-037X(2000)014[0122:PAAPIO]2.0.CO;2

[10] Rowland, M.W., Murray, D.S. and Verhalen, L.M. (1999) Full-Season Palmer Amaranth (Amaranthus palmeri) Interference with Cotton (Gossypium hirsutum). Weed Science, 47, 305-309. http://www.jstor.org/stable/4046174

[11] Gossett, B.J., Murdock, E.C. and Toler, J.E. (1992) Resistance of Palmer Amaranth (Amaranthus palmeri) to the Dinitroaniline Herbicides. Weed Technology, 6, 587-591.

[12] Wise, A.M., Grey, T.L., Prostko, E.P., Vencill, W.K. and Webster, T.M. (2009) Establishing the Geographical Distribution and Level of Acetolactate Synthase Resistance of Palmer Amaranth (Amaranthus palmeri) Accessions in Georgia. Weed Technology, 23, 214-220. https://doi.org/10.1614/WT-08-098.1

[13] Sosnoskie, L.M., Kichler, J.M., Wallace, R.D. and Culpepper, A.S. (2011) Multiple Resistance in Palmer Amaranth to Glyphosate and Pyrithiobac Confirmed in Georgia. Weed Science 59, 321-325. https://doi.org/10.1614/WS-D-10-00132.1

[14] Craigmyle, B.D., Ellis, J.M. and Bradley, K.W. (2013) Influence of Herbicide Programs on Weed Management in Soybean with Resistance to Glufosinate and 2,4-D. 
Weed Technology, 27, 78-84. https://doi.org/10.1614/WT-D-12-00099.1

[15] Grossman, K. (2009) Auxin Herbicides: Current Status of Mechanism and Mode of Action. Pest Management Science, 66, 113-120. https://doi.org/10.1002/ps.1860

[16] Anonymous (2017) Enlist Duo Herbicide Product Label. Dow AgroSciences Publication No. D02-407-003. Dow AgroSciences, Indianapolis, IN, 7 p.

[17] Robinson, A.P., Simpson, D.M. and Johnson, W.G. (2012) Summer Annual Weed Control with 2,4-D and Glyphosate. Weed Technology, 26, 657-660.

https://doi.org/10.1614/WT-D-12-00081.1

[18] Merchant, R.M., Sosnoskie, L.M., Culpepper, A.S. and Steckel, L.E. (2013) Weed Response to 2,4-D, 2,4-DB, and Dicamba Applied Alone or with Glufosinate. The Journal of Cotton Science, 17, 212-218. http://ncga.cotton.org/journal/2013-17/3/upload/JCS17-212.pdf.

[19] Miller, R.M. and Norsworthy, J.K. (2015) Evaluation of Herbicide Programs for Use in a 2,4-D-Resistant Soybean Technology for Control of Glyphosate-Resistant Palmer Amaranth (Amaranthus palmeri). Weed Technology, 30, 366-376.

https://doi.org/10.1614/WT-D-15-00129.1

[20] Jones, M.A., Greene, J.K., Marshall, M.W. and Mueller, J.D. (2017) South Carolina Cotton Grower's Guide. Clemson University Cooperative Extension Publication, EC 589, $131 \mathrm{p}$.

https://www.clemson.edu/extension/agronomy/cotton1/cottongrowersguide2017.pdf

[21] Joseph, D.D., Sanders, C.H. and Marshall, M.W. (2017) Evaluation of 2,4-D Choline Based Herbicide Systems in 2,4-D Tolerant Soybean (Glycine max L.). Agricultural Sciences, 8, 385-396. https://doi.org/10.4236/as.2017.85029

[22] Seibert, J.D., Griffin, J.L. and Jones, C.A. (2004) Red Morningglory (Ipomoea coccinea) Control with 2,4-D and Alternative Herbicides. Weed Technology, 18, 38-44. https://doi.org/10.1614/WT-03-071R1

[23] Culpepper, A.S., Gimenez, A.E., York, A.C., Batts, R.B. and Wilcut, J.W. (2001) Morningglory (Ipomoea spp.) and Large Crabgrass (Digitaria sanguinalis) Control with Glyphosate and 2,4-DB Mixtures in Glyphosate-Resistant Soybean (Glycine max). Weed Technology, 15, 56-61. https://doi.org/10.1614/0890-037X(2001)015[0056:MISALC]2.0.CO;2 